\title{
Assessment of the growth of crossbred Black-and- White and beef breed heifers until the age of 450 days
}

\author{
I. Groth, Zofia Wielgosz-Groth, Z. Kijak and Janina Pogorzelska
}

\author{
Department of Cattle Breeding, \\ Olsztyn University of Agriculture and Technology \\ Oczapowskiego 5, 10-718 Olsztyn, Poland
}

(Received 8 December 1997; accepted 25 March 1998)

\section{ABSTRACT}

Body weight and conformation were estimated as well as daily gains and feed utilization by crossbred heifers obtained by crossing Black-and-White (BW) cows with bulls of beef-type breeds: Belgian Blue (BB), Charolaise (Ch) and Limousine ( $\mathrm{Lim})$. The experiments were carried out on 43 heifers kept tied in a barn with bedding, applying controlled, intensive group feeding in the period from day 180 to day 450 of life. At the age of 180 days BW x Ch heifers were the heaviest and were significantly different $(\mathrm{P} \leq 0.01)$ from the heifers of other groups. The higher daily weight gains and better feed utilization observed for BW $\mathrm{x}$ Lim and BW $\mathrm{x}$ BB heifers were comparable to those by Charolaise sires, but the differences between groups were not significant. In respect to the body features important in meat production, no group of heifers dominated significantly over the others. $\mathrm{BW} \times \mathrm{Ch}$ heifers had a significantly $(\mathrm{P} \leq 0.05)$ higher body mass index than $\mathrm{BW} \times \mathrm{BB}$ heifers, and they had a lower index of leg height than BW x Lim heifers. BW $x$ BB heifers were characterized by the most favourable bone index, significantly $(\mathrm{P} \leq 0.01)$ lower in comparison with $\mathrm{BW} \times \mathrm{Ch}$ heifers.

KEY WORDS: heifers, crossbreeds, body weight, body parameters

\section{INTRODUCTION}

Belgian Blue (BB) cattle is rapidly gaining popularity in many European countries, as well as on other continents, due to exceptional musculature, high meat quality, favourable effects of crossbreeding, easy adaptation to various climatic and feeding conditions (Hanset et al., 1988). Bull semen of this race has been used in Poland on an experimental scale since 1991 to obtain crossbreeds with beef- 
dairy races (Rosochowicz et al., 1994). Studies on the effect of Belgian Blue bulls upon calving of Black-and-White cows and vitality of crossbred heifers in northeast Poland yielded very satisfactory results (Kijak et al., 1996). This prompted the authors to undertake further studies on the suitability of BB cattle to produce hybrids with Polish Black-and-White cattle, as compared with other typical beef races. The aim of the study was to compare the growth rate and development of heifers from Black-and-White cows by sires of beef races: Belgian Blue, Limousine and Charolaise.

\section{MATERIAL AND METHODS}

The experiments were carried out on the Jasna Agricultural Farm belonging to PHP LIDERPOL, using 43 heifers, crossbreeds obtained from BW cows by bulls of the breeds: Belgian Blue, Charolaise and Limousine. Heifers grouped into three experimental groups were obtained when aged 4 months; until then they were reared in different, relatively poor environmental conditions. The first two months were treated as a adjustment period. Throughout the entire study, from 180 to 450 days of life, the animals were kept tied in a traditional cow barn with bedding. Controlled, intensive group feeding was used, with high-quality silage of maize or grasses, dried whole maize, wheat bran, and concentrate for calves, heifers and cows. Feeds and refusals were weighed every 10 days; every time the feeds were changed, their composition and nutritive value were determined. The animals were weighed after birth, and then on days 180, 270, 360 and 450, and measured on days 180 and 450 .

The results were analyzed statistically to determine trends of growth and development, use of feeds and nutrients per kilogram of weight gain in particular genetic groups. The parameters under study were characterized statistically and the significance of differences between the mean values was established (Duncan's test). All calculations were made using SPSS software for Windows.

\section{RESULTS AND DISCUSSION}

Average body weights and daily weight gains are presented in Table 1. Heifers by Charolaise bulls aged 180 days had the highest body weights, significantly higher $(\mathrm{P} \leq 0.01)$ than heifers by $\mathrm{BB}$ and Limousine bulls, while crossbred $\mathrm{BW} \times$ $\mathrm{BB}$ heifers were significantly $(\mathrm{P} \leq 0.05)$ heavier than $\mathrm{BW} \times \mathrm{Lim}$. Daily weight gains from birth until day 180 were also the highest in the group of heifers sired by Charolaise bulls, and differed significantly $(\mathrm{P} \leq 0.01)$ from the gains of heifers in other genetic groups; the latter showed no statistically significant differences 
TABLE 1

Body weight and daily weight gains of heifers

\begin{tabular}{|c|c|c|c|c|c|c|}
\hline \multirow[t]{2}{*}{ Specification } & \multicolumn{2}{|c|}{$\begin{array}{c}\mathrm{BW} \times \mathrm{BB} \\
\mathrm{n}=12\end{array}$} & \multicolumn{2}{|c|}{$\begin{array}{c}\text { BW } \times \operatorname{Lim} \\
\mathbf{n}=15\end{array}$} & \multicolumn{2}{|c|}{$\begin{array}{c}\mathrm{BW} \times \mathrm{Ch} \\
\mathrm{n}=16\end{array}$} \\
\hline & $\mathrm{x}$ & $\mathrm{v}$ & $\mathrm{x}$ & $\mathrm{v}$ & $\mathrm{x}$ & $v$ \\
\hline \multicolumn{7}{|l|}{ Body weight, $\mathrm{kg}$ at: } \\
\hline birth & 41.37 & 9.21 & 36.26 & 7.52 & 40.50 & 7.26 \\
\hline 180 days & $151.17^{\mathrm{Ba}}$ & 11.87 & $137.73^{\mathrm{Bb}}$ & 5.76 & $169.75^{A}$ & 8.28 \\
\hline 270 days & 246.41 & 7.67 & 249.13 & 10.70 & 254.44 & 9.75 \\
\hline 360 days & 359.00 & 2.90 & 347.60 & 5.18 & 355.56 & 8.24 \\
\hline 450 days & 443.92 & 6.59 & 434.07 & 5.25 & 437.01 & 5.92 \\
\hline \multicolumn{7}{|l|}{ Daily weight gains, $\mathrm{kg}$} \\
\hline $0-180$ days & $0.610^{\mathrm{B}}$ & 13.77 & $0.564^{A}$ & 9.75 & $0.714^{\mathrm{B}}$ & 12.74 \\
\hline $180-270$ days & 1.058 & 18.81 & $1.237^{\mathrm{A}}$ & 23.68 & $0.941^{\mathrm{B}}$ & 22.21 \\
\hline $270-360$ days & 1.251 & 15.27 & 1.094 & 23.40 & 1.123 & 24.49 \\
\hline $360-450$ days & 0.943 & 24.43 & 0.961 & 22.47 & 0.905 & 26.10 \\
\hline $180-450$ days & 1.084 & 12.55 & 1.097 & 7.38 & 0.990 & 8.99 \\
\hline $0-450$ days & 0.896 & 7.37 & 0.885 & 5.76 & 0.880 & 5.98 \\
\hline
\end{tabular}

$\mathrm{a}, \mathrm{b}-\mathrm{P} \leq 0.05 ; \mathrm{A}, \mathrm{B}-\mathrm{P} \leq 0.01$

$(\mathrm{P}>0.05)$. The relatively low weight and daily gains of crossbred heifers resulted from poor environmental conditions during rearing. The weight of the 270 -dayold heifers days was similar. Catch-up growth was observed in all experimental groups from day 180 to day 270 of life. Daily weight gains were very high in this period. The highest values were observed in BW x Lim heifers, which had showed the slowest growth in the first 180 days of life. However, the weight gains from birth until day 270 of life were lower than in the studies of Gerhardy and Griepenkerl (1994), in which Fresian x BB crossbreeds fed intensively until a body weight of $310 \mathrm{~kg}$ (age about 270 days) attained $996 \mathrm{~g}$ daily gains, whereas Fresian x Ch crossbreeds attained $60 \mathrm{~g}$ lower daily gains.

The highest body weight at the age of 360 and 450 days was observed in crossbred BW x BB heifers, the lowest in crossbreeds by Limousine bulls. Still, the differences between the genetic groups were statistically insignificant $(\mathrm{P}>0.05)$. The body weight of BW x Lim heifers aged 360 days was much higher than in the case of the same crossbreeds studied by Trela et al. (1990). On the other hand, the body weight of crossbreeds by Charolaise and Limousine sires was higher at the age of 450 days than in the experiments of de Laurans et al. (1989), Goszczyński et al. (1990) and Zalewski et al. (1991), in which the animals were fattened semiintensively and extensively till 18 months of life. BW x Lim heifers showed the highest daily weight gains between day 180 and 450 of life, but the highest gains from birth until day 450 were attained by crossbreeds by BB bulls. The high body 
TABLE 2

Use of feeds and nutrients per $1 \mathrm{~kg}$ of body weight gain

\begin{tabular}{lcccc}
\hline & Specification & BW x BB & BW x Lim & BW x Ch \\
\hline Silage, kg & Period, days & & & \\
& $180-270$ days & 10.90 & 11.20 & 12.63 \\
& $270-360$ days & 12.83 & 12.38 & 13.08 \\
& $360-450$ days & 17.26 & 15.23 & 17.86 \\
& $180-450$ days & 13.66 & 12.60 & 14.52 \\
Concentrate mixture, kg & & & & \\
& $180-270$ days & 3.20 & 3.10 & 3.59 \\
& $270-360$ days & 3.36 & 3.35 & 3.89 \\
& $360-450$ days & 4.26 & 4.21 & 4.42 \\
Metabolizable energy, MJ & $180-470$ days & 3.61 & 3.55 & 3.97 \\
& $180-270$ days & 28.85 & 28.14 & 32.10 \\
& $270-360$ days & 31.27 & 30.68 & 34.28 \\
& $360-450$ days & 40.95 & 38.41 & 42.48 \\
Crude protein, g & $180-450$ days & 33.69 & 32.39 & 36.29 \\
& $180-270$ days & 630 & 622 & 715 \\
Dry matter, kg & $270-360$ days & 678 & 668 & 756 \\
& $360-450$ days & 874 & 837 & 910 \\
& $180-450$ days & 727 & 710 & 793 \\
& $180-270$ days & 5.51 & 5.36 & 6.15 \\
& $270-360$ days & 5.97 & 5.86 & 6.50 \\
& $360-450$ days & 7.81 & 7.29 & 8.10 \\
& $180-450$ days & 6.43 & 6.17 & 6.92 \\
\hline
\end{tabular}

weights of heifers in the analyzed groups of crossbreeds aged 360 and 450 days, and high daily weight gains confirm that the feeding regime was intensive during the experiment. Intensive feeding, resulting in high gains, led to very low use of feeds and nutrients per kilogram of weight gain (Table 2) compared with the results obtained in earlier studies (de Laurans et al., 1989, Goszczyński et al., 1990; Zalewski et al., 1991).

The best feed utilization and nutrients per $\mathrm{kg}$ of weight gain for the whole period studied was attained by BW x Lim crossbreeds. These heifers were also characterized by the highest daily gains. The worse feed utilization was observed for BW x Ch heifers, which also showed the lowest gains. Nevertheless, the differences between the groups were small and statistically insignificant $(\mathrm{P}>0.05)$.

The basic body conformation parameters of the crossbred heifers are presented in Figures 1 and 2. The height of 180-day-old crossbreeds after BB and Ch bulls was very similar. Heifers after Limousine bulls were a few centimeters lower, but 


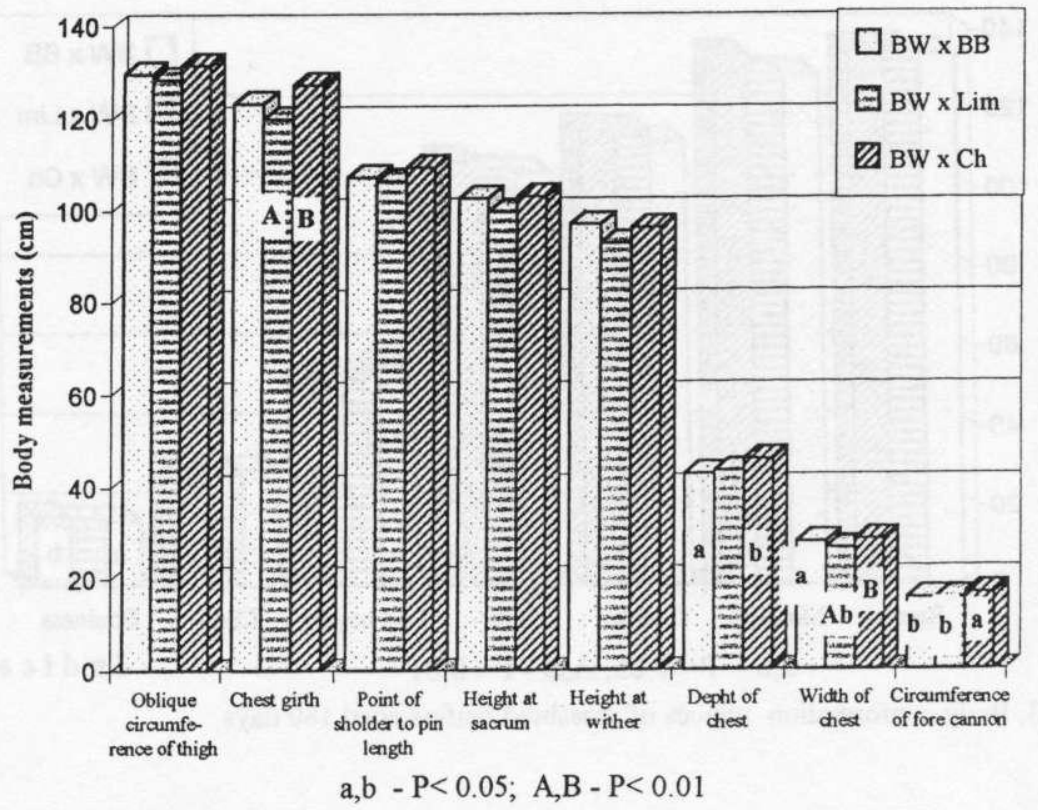

Figure 1. Body measurements of crossbred heifers aged 180 days

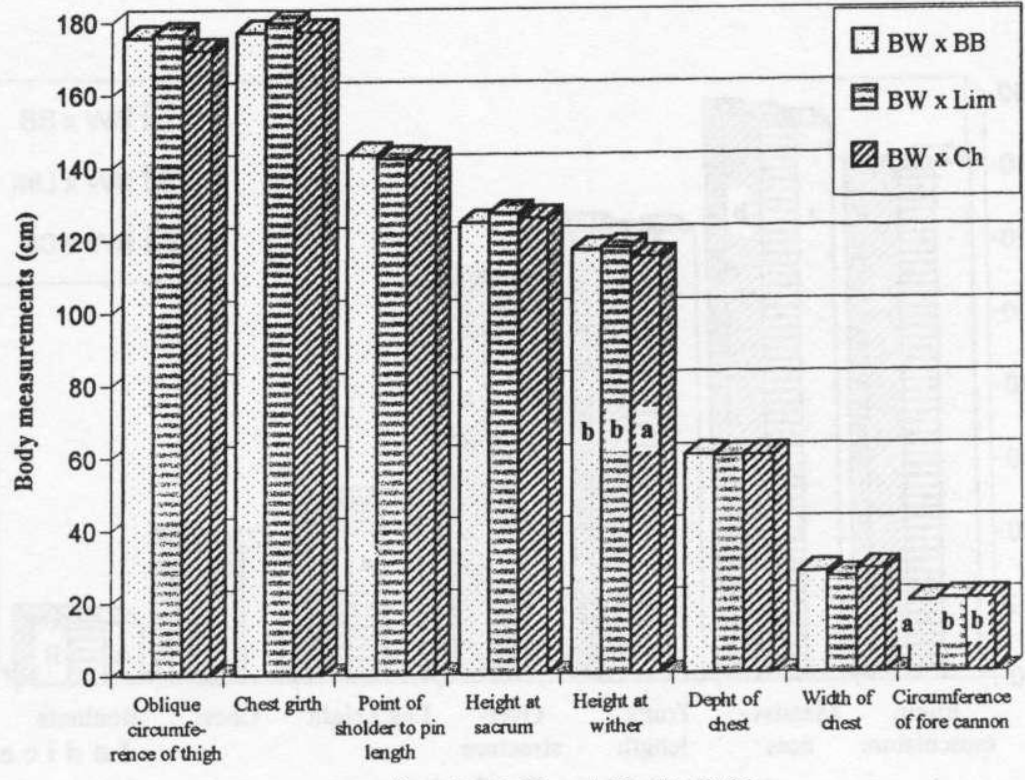

$$
\text { a,b - P }<0.05 ; \mathrm{A}, \mathrm{B}-\mathrm{P}<0.01
$$

Figure 2. Body measurements of crossbred heifers aged 450 days 


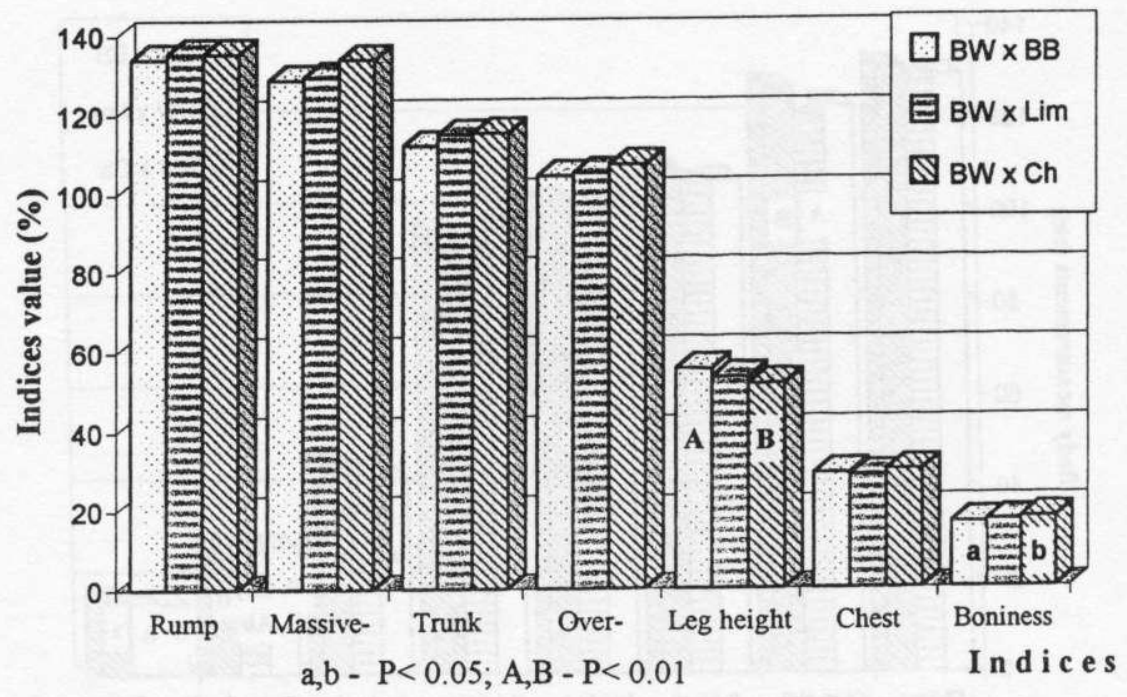

Figure 3. Body conformation indices of crossbred heifers aged 180 days

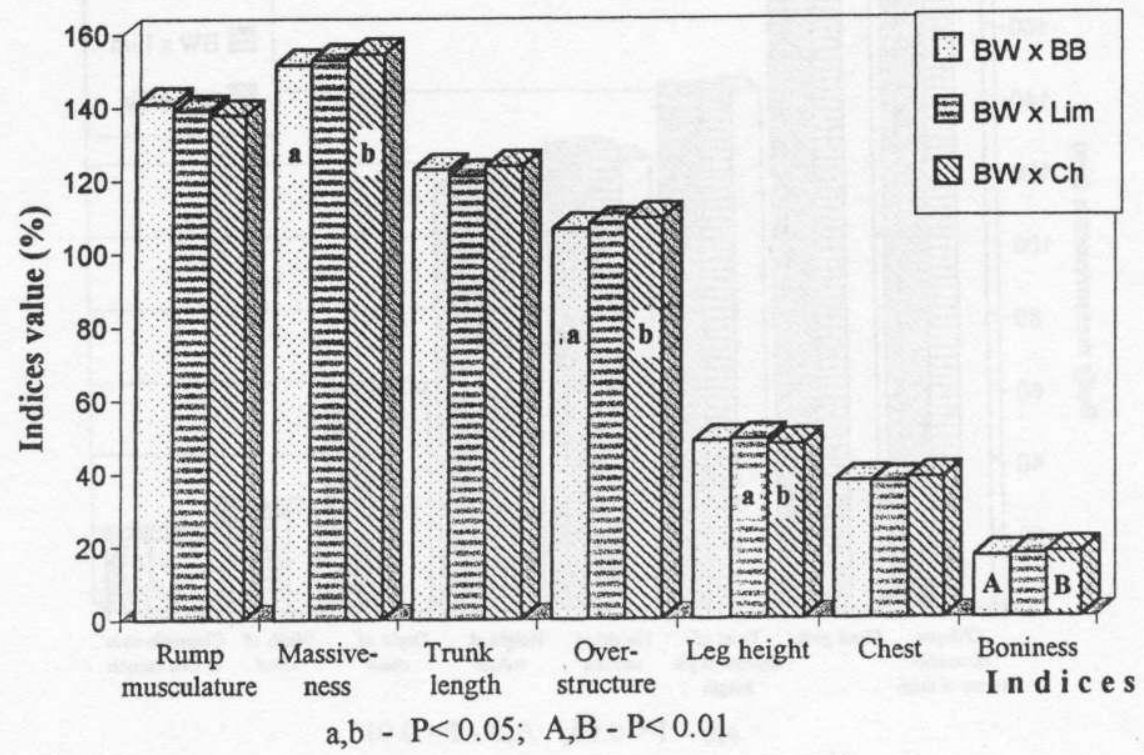

Figure 3. Body conformation indices of crossbred heifers aged 450 days 
the differences were not significant $(\mathrm{P}>0.05)$. BW $x$ Ch heifers aged 450 days were significantly $(\mathrm{P} \leq 0.01)$ lower than the heifers in other groups. At the age of 180 days crossbred heifers after Charolaise bulls had the largest chests, which were significantly $(\mathrm{P} \leq 0.01)$ larger than in heifers after Limousine bulls. By the age of 450 days, chest dimensions did not differ much among the particular groups. In regards to trunk length, $\mathrm{BW} \times \mathrm{Ch}$ heifers aged 180 days had the longest, while those after Limousine bulls had the shortest. At the age of 450 days, heifers after BB bulls had the longest trunks ( $143.24 \mathrm{~cm}$ on average), and heifers after Limousine and Charolaise bulls were $1 \mathrm{~cm}$ shorter, but these differences were not significant $(\mathrm{P}>0.05)$. Heifers after Charolaise bulls at the age of 180 days had the best thigh muscles, but by day 450 of life they were surpassed by BW x Lim crossbreeds. The thickest legs were observed in heifers after Charolaise bulls, both at the age of 180 (significant difference at $\mathrm{P}<0.05$ ) and 450 days. BW x BB crossbreeds aged 450 days had the smallest fore cannon circumference, and the difference was significant $(\mathrm{P}<0.05)$.

Body parameters show that the heifers were proportional; they also enable estimation of carcass quality. The basic indices of body conformation in the analyzed groups of crossbred heifers are presented in Figures 3 and 4. The highest index of body mass in 180-day-old animals was observed for heifers after Charolaise bulls, while the lowest indices were noted in heifers after BB bulls. Regarding the animals aged 450 days, the body mass index in heifers after Charolaise bulls was significantly different $(\mathrm{P}<0.05)$ than in heifers after $\mathrm{BB}$ bulls. The trunk length indices in 180-day-old animals were the most satisfactory (the largest) in heifers after Charolaise bulls, slightly lower in BW x Lim heifers, and the poorest in heifers sired by BB bulls, but the differences were not significant $(\mathrm{P}>0.05)$. In heifers aged 450 days the poorest trunk length index was observed in BW x Lim crossbreeds, but also in this case the differences between this and other heifer groups were insignificant. The leg height index was the lowest in $\mathrm{BW} x \mathrm{Ch}$ heifers and differed significantly $(\mathrm{P}<0.01)$ from this index in heifers after $\mathrm{BB}$ bulls aged 180 days, and from BW $x$ Lim heifers aged 450 days $(\mathrm{P}<0.05)$. Chest indices in heifers aged 180 days were similar in all groups. At the age of 450 days the highest chest index was observed in heifers after Charolaise bulls, while in the other two groups these indices were a little lower and similar. The rump was most overstructured in heifers after Charolaise bulls, both after 180 and 450 days of life, the least in heifers after BB bulls. The rump muscle index (oblique circumference of thigh : height at sacrum $\times 100$ ) on day 180 was similar in all groups, but in the case of animals aged 450 days it was most satisfactory in crossbred BW x BB heifers. Heifers after BB bulls had the lowest, i.e. the most satisfactory, bone index. This index differed significantly from $\mathrm{BW} \times \mathrm{Ch}$ heifers both on day $180(\mathrm{P}<0.05)$ and $450(\mathrm{P}<0.01)$. 


\section{CONCLUSIONS}

At the age of 180 days BW x Ch heifers had significantly $(\mathrm{P}<0.01)$ higher body weight and body parameters than the heifers from other groups. In the period from 180 to 450 days of life, due to intensive feeding, heifers from all experimental groups attained high daily weight gains and final body weight. BW $\mathrm{x}$ Lim and BW $x$ BB heifers in this period had high daily weight gains and utilized feeds better than the heifers after Charolaise bulls, but the difference between groups was not significant.

Body parameters and formation indices in heifers aged 450 days did not clearly distinguish any group of heifers as far as their meat utilization was concerned.

\section{REFERENCES}

De Laurans A., Reklewski Z., Goszczyński J., Kretkiewicz. G., 1989. Meat and carcass quality of crossbred heifers (BW x bulls of meat varieties) fed mostly grass silage (in Polish). Proceedings of Conference „Cattle breeding and directions of cattle production on pasture lands", Pawłowice (Poland), pp. 137-145

Gerhardy H., Griepenkerl L., 1994. Cereal beef production from crossbred heifers. Arch. Tierzucht $37,481-492$

Goszczyński J., de Laurans A., Reklewski Z., 1990. Comparison of slaughter yield of female progeny of extensively fed bulls of meat varieties (in Polish). Proceedings of Conference „Cattle breeding and directions of cattle production on pasture lands", Slawa Sląska (Poland), pp. I45-151

Hanset R., Detal G., Michaux C., 1988. Growth and carcass characteristics of crossbred bults from Friesian and MRY dams by Belgian Blue sires. Proceedings of 3rd World Congress on Sheep and Beef Cattle Breeding. Vol. 2, 176-178

Kijak Z., Groth I., Pogorzelska J., Wronski M., Wielgosz-Groth Z., Mordas W., 1996. Course of calving and quality evaluations of calves produced by crossing Black-and-White cows with bults of the Belgian Blue breed (in Polish). Acta Acad. Agric. Tech. Olst., Zoot., 45, 62-70

Rosochowicz Ł., Kliks R., Pruszewicz P., 1994. Calving of BW cows crossbred with Belgian Blue bulls (in Polish). Prz. hod., Zesz. nauk. No 14, „Cattle production and breeding”, p. 361

Trela J., Choroszy Z., Makola K., Czaja H., Bobik K., Herman J., Fenrych W., Janowski W., Pietras H., 1990. Works aimed at creating a stock of meat-type cattle- breeding and selection of bulls used for commercial crossbreeding (in Polish). Biul. inf. Inst. Zoot. 28 (3-4), 13-29

Zalewski W., Kamieniecki K., Jasińska E., Szwarc B., 1991. Carcass characteristics and yield and sensoric estimation of meat quality of crossbreeds from BW cows by Simental and Limousine bulls (in Polish). Prz. hod. Zesz. nauk. No 3, „Cattle production and breeding”, pp. 239-244 


\section{STRESZCZENIE}

\section{Ocena wzrostu jałówek mieszańców rasy czarno-białej z rasami mięsnymi do wieku 450 dni}

Oceniano masę i budowę ciała, przyrosty dobowe i zużycie pasz u jałówek pochodzących z krzyżowania krów rasy czarno-białej $(\mathrm{BW}) \mathrm{z}$ buhajami ras mięsnych: belgijskiej biało-błękitnej (BB), charolaise (Ch) i limousine (Lim). Doświadczenie przeprowadzono na 43 jałówkach, utrzymywanych na uwięzi w oborze ściołowej, stosując kontrolowane, intensywne żywienie grupowe od 180 do 450 dnia życia. W wieku 180 dni najcięższe były jałówki BW x Ch, różniąc się istotnie $(\mathrm{P} \leq 0,01)$ od jałówek z pozostałych grup. W okresie doświadczenia jałówki BW x Lim i BW x BB miały większe przyrosty dobowe i lepiej wykorzystywały pasze niż jałówki po buhajach rasy charolaise, ale różnice pomiędzy grupami nie były istotne. Pod względem cech budowy ciała, ważnych dla użytkowania mięsnego, żadna grupa jałówek nie dominowała nad pozostałymi. Jałówki BW x Ch miały jedynie istotnie $(\mathrm{P} \leq 0,05)$ większy indeks masywności w porównaniu z jałówkami BW x BB i istotnie mniejszy indeks wysokonożności niż jałówki BW x Lim. Natomiast mieszańce BW x BB wyróżniał najkorzystniejszy, istotnie $(\mathrm{P} \leq 0,01)$ mniejszy w porównaniu z jałówkami $\mathrm{BW} \times \mathrm{Ch}$, indeks kościstości. 